\title{
Chapter 2 \\ Restructuring of Agriculture and the Rural World in Mediterranean EU Countries
}

Agriculture and rural development represent critical domains for the economy, the society as well as the ecosystems of Euro-Mediterranean countries. Important changes and challenges have though reconfigured food production, natural resource management as well as rural livelihoods in recent decades in the region.

Main distinct but intertwined processes include: (i) Agricultural modernization and polarization; (ii) The restructuring of agri-food chains in the global market; (iii) The institutionalization of the agrarian world, including the role of the Common Agricultural Policy (CAP).

These processes have resulted in an increasing demand for lower-waged workers and the socio-economic marginalisation of rural communities, reducing the local attractiveness of agriculture and rural livelihoods. The reconfiguration of agricultural labour has resulted in a restructuring of its manpower, with a significant shift from family labour to a salaried, foreign one. It is within such framework that the consistent and growing presence of immigrants in rural areas and agricultural sector is to be assessed. The focus is on EUMed countries (Greece, Spain, and Italy), which present some specific and characterising features and dynamics.

\subsection{A Focus on the Agrarian World of Mediterranean Europe}

In recent decades the presence of migrants in rural areas has increased, stimulated by a growing demand for low-cost agricultural labour. In this chapter we will analyze the changes of the agrarian world and their links with migrations. 
Agriculture continues to play a strong role in rural areas of Mediterranean countries in the European Union (EUMed from here onwards ${ }^{1}$ ), as it defines social, environmental, economic as well as cultural identities. Agricultural products and rural tourism contribute consistently to national GDPs, and rural communities play a critical role in the management of biodiversity in Mediterranean ecosystems, where desertification is a threat. ${ }^{2}$ A typical indicator exemplifying the relevance of agriculture in the EUMed compared to other European regions is that half of the agriculturally employed population and two-thirds of farm holdings in the EU-15 were concentrated in the European south (EU 2012).

Agriculture and rural societies in Europe have undergone critical changes and reconfiguration since WW II characterized by these three main distinct but intertwined processes:

1. Agricultural modernization and polarization;

2. The restructuring of agri-food chains in the global market;

3. The institutionalization of the agrarian world, including the role of the Common Agricultural Policy (CAP).

The substantial influx of immigrant communities in rural settings today is a consequence of this restructuring.

The modernization of agriculture has hinged on a market-oriented vision, which has promoted productivity over any other aspect of farming and rural development. Such processes have favoured investments mostly in areas with high potential for agriculture intensification, while those areas considered more marginal due to their agro-ecological features lagged in attracting political attention and financial investment. Polarization thus started to reshape the rural world in geographical as well as in socio-economic terms.

These dynamics accelerated in the nineties, when EUMed agriculture became deeply integrated into global agricultural food chains which encouraged specialised productions oriented to fresh consumption and processing. Tomatoes, oranges, strawberries, olives, fruits, wines, cheeses produced in southern Europe started to serve the increasingly growing global consumption demand. The resulting process was supported, amongst others, by public policies and funding through the Common Agriculture Policy (CAP). Today the top export markets for most of EUMed's fruits and vegetables are Germany, Austria, Switzerland, France, Sweden, and the UK, while wines and cheeses are largely exported to the US, Russia and China.

The incorporation of the EUMed agri-food into globalized chains has highly impacted farmers, who have found themselves in a subaltern role, facing high price competition, squeezed by decreasing prices dictated by the market, with reduced profit margins and eroded negotiation power in international trade systems. The

\footnotetext{
${ }^{1}$ Implying mainly Greece, Spain and Italy, though parts of Portugal and France pertain as well to the region.

${ }^{2}$ The Mediterranean region represents the second world biodiversity hotspot, and one of the regions most impacted by climate change according to UNEP (2010) and to IPCC (2014).
} 
modern agricultural restyling has shifted socio-economic roles and relationships; many farmers ceasing their activities, while those remaining have been forced to cut down on production costs, including labour.

This sequence of events has resulted in an increasing demand for lower-waged workers, which has contributed to reducing the local attractiveness of agricultural work. The reconfiguration of agricultural labour has resulted in a restructuring of its manpower, with a significant shift from family-labour to externally-sourced, salaried work. In parallel there has been a shift from hiring a more local to a more foreign workforce. It is in this framework, where the presence of immigrants in farming activities is growing, that needs to be assessed.

This context applies specifically to EUMed countries where agricultural labour is normally temporary and precarious and requires workers to move according to seasonal agriculture demands, specifically for harvesting. The growing demand for a flexible, low-skilled and cheap labour and the decreasing interest shown by local populations explains why EUMed rural areas have become increasingly attractive for immigrants.

In this chapter, we will provide a general overview of these processes and the related changes and impacts in relation to the restructuring of agriculture and rural areas during recent decades. Our focus is on EUMed countries, which present some specific and characterising features when analysing these dynamics.

\subsection{The Impacts of Agricultural Modernization}

In traditional Mediterranean agricultural systems, the most typical labour configuration has been family-based work in the form of self-employment and informal labour from family members. EUMed countries have a long agrarian tradition whereby cultivated land, crops and livestock are based on the family farm and on its labour, though a system that aims at ensuring the production as well as the reproduction of the farming system. Specifically, for smallholders, as well as taking care of their farm production system, members of peasant households would also lend their work seasonally to larger farms. This model changed rapidly since the end of the World War, when European rural areas have undergone an important process of agricultural modernization, instilled also by the Community Agricultural Policy (CAP) (on this debate see Hervieu and Purseigle 2012; Arnalte-Alegre and OrtizMiranda 2013; Ortiz-Miranda et al. 2013; Agnoletti 2013; Angonelli and Emanueli 2016). This process implied the decline of the peasant agricultural model which hinged on multi-functionality, polyculture, self-consumption, and the redundancy of internal production factors, including family labour (Van der Ploeg 2013).

The modernization pull, towards a new market-orientation and market-integration of agricultural systems, has aimed to increase production and reduce costs (Van der Ploeg 2008, 2010). The aim to enhance agricultural "industrialization", through a "green revolution", has pushed for the intensification of production based on sectoral 
specialization, monoculture, standardisation and replicability; largely thanks to the application of tailored technologies as well as of dedicated chemical, agronomic and genetic sciences. The introduction of labour-saving machinery eventually triggered a crowding-out of rural populations. This in turn led to urbanization, to the growth of waged-labour and to the related transformation of the farmer from peasant to agricultural entrepreneur (Hervieu and Purseigle 2012). This also meant a "masculinization" of farming: women were increasingly marginalised from farming operations or assigned an auxiliary role in the farm economy, as they looked for employment in non-farm sectors (Saugeres 2002; Bharadwaj et al. 2013).

The restructuring of the agriculture world that has characterized recent economic development has contributed to the intensification of social and spatial differentiations in the rural world, with several relevant implications on farming and on farmers (Van der Ploeg 2008; Hervieu and Puseigle 2012). Agriculture has become increasingly integrated and dependent on market dynamics both upstream and downstream. Producers have lost their autonomy and have been forced to: acquire most production inputs (raw materials, technologies and other industrial inputs such as feed, seeds, pesticides, fertilizers, chemicals, genetics, oil and energy) on the market, and sell their products (the farm output) on the international market (Friedmann 2005).

The farming system increasingly lost its capacity to ensure the internal reproduction of its' means of production. Soil fertility is recovered through chemical fertilizers, plant and animal genetics elaborated elsewhere and acquired through the market, manpower either replaced by machines or scaled down to waged-labour. In this model, most of the farm's output is devoted to market exchanges. Generating income becomes necessary to purchase production inputs. Moreover, agricultural goods have become commodities in a global market, with high price volatility, hierarchical networks and decreasing returns to producers. As we will describe, all these factors have contributed to creating a subordinate position for producers, both in the value chains regulating distribution, and for the commercialization of their outputs.

These processes increase the phenomenon of the farm cost-price squeeze, caused by the growing gap between the Gross Value of Production (GVP) and the production costs incurred by the farmer. To maintain sufficient income, farmers have to increase the size of the enterprise in order to cut down on costs per unit. This eventually leads to a vicious circle whereby farm size is dictated by market prices and costs, and the farmers are squeezed by costs of production which increase faster than the price of their products (Moss 1992; Shield 2009).

The crisis of the agrarian world can be witnessed in the historical drop of farmer income, which eventually triggered the disqualification of agricultural work, the significant rates of land abandonment and the decline in number of farms, with related problems of rural exodus and "socio-economic desertification", as it will be assessed. Today rural areas in large parts of the EU are characterized by a declining and ageing population, low workforce availability and limited generational renewal. The low and decreasing percentage of young farmers in EU countries is considered a major problem for the future of agriculture. A short-term strategy relies on the increasing use of migrant workers to make up for the shortage of local labor. 
However, in marginal territories, this process carries longer-term consequences for the reproduction of local societies. Furthermore, the abandonment of agriculture and land provokes a degradation of natural resources, the loss of ecological and cultural biodiversity, and a growth in regional disparities. Together these dynamics are seen to threaten the sustainability of agriculture, food systems and rural lifestyles (EU 2012; Zagata and Sutherland 2015; Nori 2017; SOFA 2018).

\subsection{The Restructuring of Agri-Food Chains in the Global Market}

The negative effects of agricultural modernization were amplified at the beginning of the 1990s, when neo-liberal processes of global restructuring of the agro-food supply chain contributed to unbalancing market relations, and increasing the power of large corporations through processes of unfair liberalization.

In economic theory, a supply chain includes different kinds of economic actors, operating in one or more phases of the chain and differing by size and economic power with varying degrees of relationships. The agri-food chain links producers to end consumers, and it consists of four distinct and consequent phases (Fig. 2.1):

1. Production of raw food, in which the companies operating in the primary sector are located (agriculture, livestock, fisheries). In this phase we find farmers, either independent or in cooperatives. Generally farmers are fragmented and small in size.

2. Transformation of raw materials, which involves attention to processing and manufacturing activities, be they industrial or artisanal. Food producers are of different sizes: small, medium (SME) and large enterprises, each one exhibiting and displaying different power and capacity to relate to other actors along the chain.

3. Packaging and labelling, which can be carried out both by the processing companies themselves or "purchased" by other service companies operating on the market.

4. Distribution and marketing, in which commercial and intermediary activities are located between the producer and the final consumer. Here we have a variegated universe from SMEs to large international groups and distributors, from small corner shops to supermarkets chains.

The two extremes of the chain show the largest degrees of risk and vulnerability. On the one hand the more intermediaries there are, the longer the supply chain and the lower the value and the control displayed by the producers. In addition, the longer the chain, the less control the consumers hold on it, since a high number of intermediary steps increases the information asymmetry to the detriment of the final user, despite the different measures of product traceability. 


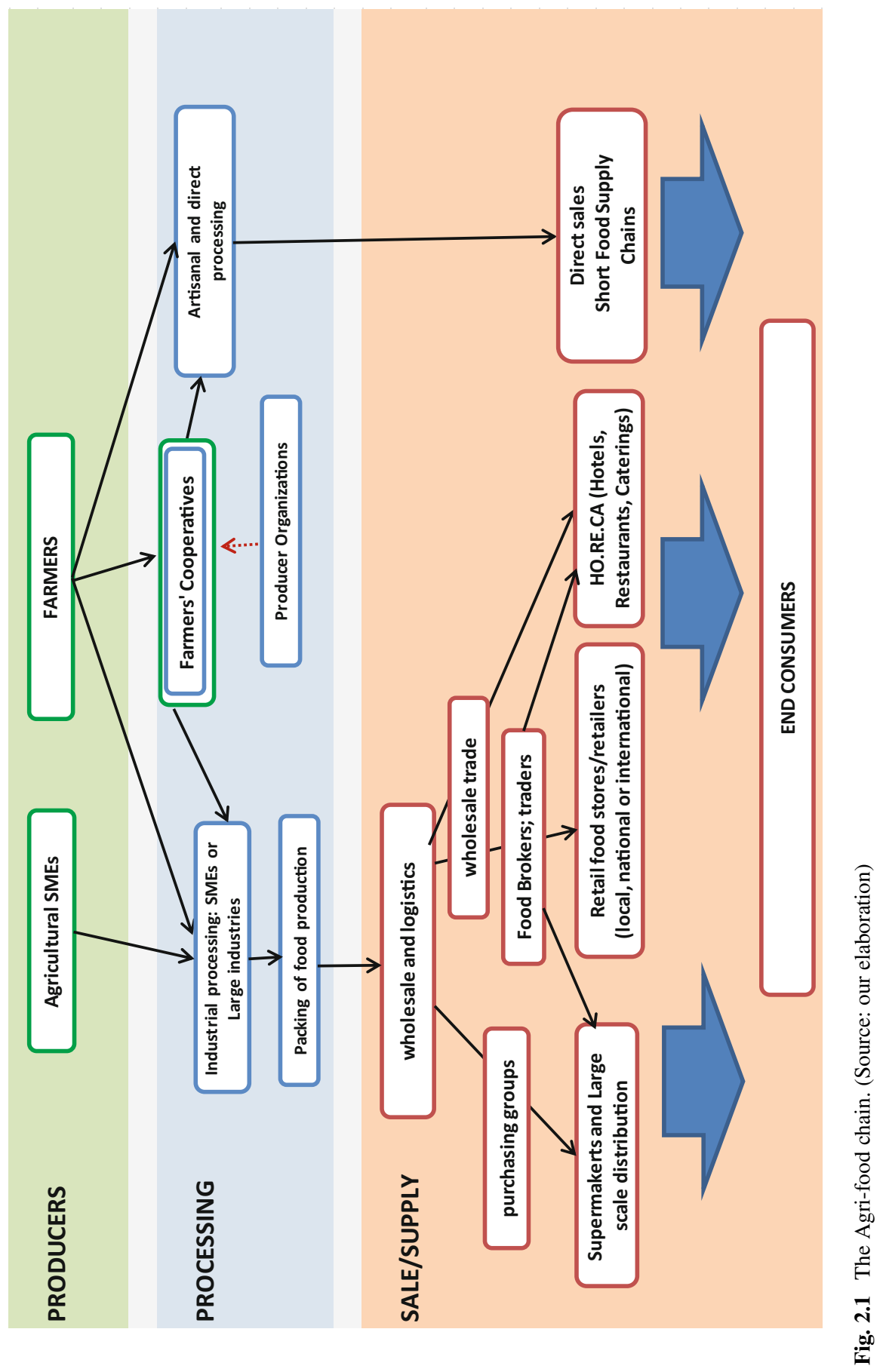


On the other hand, a supply chain is short when there is a direct relationship between the producer (often also the processor) and the final consumer, without much distributive intermediation. Since the 2000s different types of Short Food Supply Chains (SFSC) and Alternative Food Networks (AFN) have spread as alternatives to mass production and large-scale organized distribution, in support of an agriculture embedded in the territory where the symbolic and relational values of food are also accounted for.

\section{Box: Shorty Food Supply Chains and Alternative Food Network}

The Short Food Supply Chain is an umbrella term to identify all alternative "short-circuits" that shifts from an 'industrial mode' of production and supply, engendering different relationships between producers and consumers (Mardsen et al. 2000):

A key characteristic of short supply chains is their capacity to re-socialize or re-spatialize food, thereby allowing the consumer to make value-judgements about the relative desirability of foods based on of their own knowledge, experience, or perceived imagery. Commonly, such foods are defined either by the locality or even the specific farm where they are produced; and they serve to draw upon and enhance an image of the farm and/or region as a source of quality foods. 'Short' supply chains seek to redefine the producer-consumer relation by giving clear signals as to the origin of the food product. Short supply chains are also expressions of attempts (or struggles) by producers and consumers alike to match new types of supply and demand. Notable here are the additional identifiers which link price with quality criteria and the construction of quality. A common characteristic, however, is the emphasis upon the type of relationship between the producer and the consumer in these supply chains, and the role of this relationship in constructing value and meaning, rather than solely the type of product itself.

However, the Short Food Supply Chains represent a minority part of the global agri-food, which is characterized by an increasing concentration of retail corporate power over agricultural production. The restructuring of global value chains has been pushed by the neoliberal globalization (in 1990s), through several intertwined processes (Corrado et al. 2016a: 7):

The incorporation of agricultural production in vertical food chains controlled by transnational corporations, the transformation from producer-driven to buyer-driven food chains (Burch and Lawrence 2007), the consolidation of retailer power through the supermarket revolution (Reardon et al. 2003; McMichael and Friedmann 2007), and the financialization of agricultural processes have all reshaped the global agri-food system and the connections between the global North and the global South.

As a result of this restructuring, distributors dispossess producers from leading the agri-food supply chains, whose hierarchy becomes vertically integrated, controlled and operated by transnational corporations that operate mainly in the distribution phase. These transnational corporations end up as intermediates to all relations that control the market, manipulating the functioning of agri-food chains to their advantage. Through an increasingly unfair distribution of risks, costs, and 
profits along the chain, food industries and retailers use their oligopolistic power of negotiation to impose price and contractual conditions on farmers, thus coming to weaken their managerial and economic capacities.

This "retailing revolution" is defined by agri-food chains progressively restructured in hierarchical networks, characterised by high price volatility, and decreasing returns to producers (McMichael and Friedmann 2007).

Using their asymmetric power in the distribution stage, large supermarket chains operate as "food authorities (Dixon 2007), imposing private standards upon agricultural production through retailer-driven agri-food supply chains" (Corrado et al. 2016a: 12), and control and affect as well other phases along the chain such as production, processing and consumption (Burch and Lawrence 2007). Van der Ploeg describes this phenomenon of lost autonomy from producers and consumers with the image of the "food empire" in which "it is becoming difficult, if not often impossible, for farmers to sell food ingredients or for consumers to buy food outside of the circuits that they control" (Van der Ploeg 2010: 101).

Furthermore, the effective role and power of big transnational supermarket chains overcome the mere food chain, as these become able to influence the policies of nation states, pushing towards liberalizations that consolidate their power, both in developing countries and in those with an advanced economy. This has resulted in the crisis of small traders and retailers because the possibility to sell to the market passed to a few buying groups, that can impose their contractual conditions and prices (Vorley 2007).

\section{Box: Expansion and Concentration of Agro-food Value Chains}

Corrado et al. (2016a: 12) summarize the expansion and concentration of European agro-food value chain:

Europe's top 10 retail groups are headquartered in three countries: the UK, France and Germany. For example, in 2010, Carrefour (France) - Europe's largest retailer ahead of the Metro Group (Germany) and Tesco (UK) and second only to US-based Wal-Mart at the global level - employed 475,000 workers and had 15,600 companyoperated or franchised stores in 34 countries across the world, with $57 \%$ of its turnover coming from outside France (Fritz 2011) [...] In Italy, large retailers' share of the food market grew from 44\% in 1996 to 71\% in 2011 (AGCM 2013). In Greece, the four largest retailers (three foreign chains and one national company) accounted for $55 \%$ of the sales and more than $80 \%$ of the profits of the national grocery retail market in 2009 (Skordili 2013). In Spain, big retailers controlled 63.7\% of the food market in 2014 (ANGED 2014: 36). In Morocco, supermarket trade took off in the early 2000 s, with the arrival of foreign direct investments, mainly by the French Auchan group.

Through the World Trade Organization's (WTO) negotiations of the General Agreement on Trade and Services (GATS) and other free-trade policies adopted amongst others also by the EU, the supermarket chains can buy agricultural products almost all over the world, regardless of the place of production, the seasons and the transportation costs. Including in countries where prices are lower due to less 
stringent environmental and labor regulation. The dual objective is to buy at the lowest price and to stimulate producers to keep their prices low (Vorley 2007; Gertel and Sippel 2014; Corrado et al. 2016b; Oxfam 2018). This process and the related squeeze affect affects agriculture all over, through an increasing exploitation of labour and land, with visible effects on the conditions of the environment, the quality of the food and the rights and conditions of workers.

Many researchers have investigated the different mechanisms through which distribution transnationals are able to buy at increasingly lower prices, transferring costs to farmers, who increasingly suffer from the agricultural squeeze. The supermarket chains impose on producers many "quality standards" linked to different aspects of production (in particular, high-quantity, low prices, quality, packaging, environment and food safety) that marginalize small farmers and artisanal producers, for whom the adjustment to these parameters is often difficult and expensive (Burch et al. 2013; Burch and Lawrence 2013; Richards et al. 2013). This mechanism is even more aggravated by the system of "private labels", a way through which the supermarket chains buy agri-food products and distribute them under their own brand labels, turning into "food business operators" (Vorley 2007).

Farmers are forced into unfair contracts with unilateral conditions and retroactive unfair changes to working contracts or unjustified threat of termination of contracts, ${ }^{3}$ and practices bordering illegality, especially when they are small and medium-sized enterprises (SMEs), with a subaltern and weak position in the supply chain. There have been many reports and campaigns denouncing the unbalanced functioning of a global agri-food supply chain, also in the case of EU countries.

\section{Box: The Agricultural Squeeze in EU-Countries}

In 2009 the European Commission confirmed the dramatic situation in which farmers saw their added value increasingly eroded to the advantage of the distribution phase (EU 2009: 7 ss.):

Total value-added for the food supply chain in the EU25 in 2005 was €540 billion, i.e. $5.2 \%$ of the total value-added of the European economy. The agricultural sector represented $24 \%$ of this total, the food industry $33 \%$ and the distribution sector $43 \%$ ( $13 \%$ for wholesale and $30 \%$ for retail). The value-added of each sector is thus increasing moving downwards along the chain: In 2005 , the food industry valueadded was 1.4 bigger than the value-added of agriculture and the distribution sector was 1.3 bigger than the food industry. Agriculture value-added has declined over the 1995-2005 decade, with a $1.5 \%$ per year decrease. [...] in the meanwhile, the other sectors of the chain have grown over the period [...] consequently, the pattern of distribution of value-added across the food supply chain has significantly changed in the EU25 during the 1995-2005 decade. The share of agricultural industry has consistently decreased under the combined effect of its negative value-added growth

(continued)

\footnotetext{
${ }^{3}$ On these aspects see: European Commission, 29 January 2016, Report on unfair business-tobusiness trading practices in the food supply chain.
} 
and the much more dynamic growth of the other sectors. The share of agriculture in food supply chain has decreased from $31 \%$ in 1995 (equal to the share of the food industry) to $24 \%$ in 2005 (with a food industry at $33 \%$ ). The distribution sector has increased its share in the same period by $2 \%$ for the food wholesale sector (from $11 \%$ in 1995 to $13 \%$ in 2005 and by $3 \%$ for the food retail sector (from $27 \%$ to $30 \%$ ).

The brunt of such impacts is typically borne by those holding a subordinate position within the value chain: on the one hand, farmers and their workers and on the other the final consumers. The general trend has been a loss of food sovereignty, decreased control on the quality of the production process and increasing dependence on unstable and volatile global market.

In a continuous race to the bottom, the farmers try to extract the lost value in the chain, making more use of two main productive factors, land and work. This leads to the exhaustion of the natural resopurce base on the one hand, and greater degrees of exploitation of the weaker and more precarious labor, often represented by immigrants, on the other.

\subsection{The Institutionalization of the Agrarian World and the Role of the Common Agricultural Policy}

The policy framework has therefore played a considerable and ambivalent role in the process of agricultural modernization and the oligopolistic restructuring of the global agri-food chain including in the EU with its prominent Common Agricultural Policy (CAP). CAP represents a main pillar of the European Union, and one of its main relevant policy axes; in 2018 it still engaged about $40 \%$ of the overall EU budget. The CAP was introduced in 1962, and for the first two decades it mainly spurred agricultural production within a framework of modernization of agriculture and the development of the global agri-food chain. This approach led to excess food supply and related market distortions, which eventually induced CAP reforms to better account for different aspects of European rural development within a more multifunctional perspective.

Overproduction, environmental problems, and consumer concerns for health and quality motivated CAP reforms through measures such as the reduction of price supports (through the 1992 MacSharry reform), cross-compliance with environmental objectives and support to agricultural multifunctionality and rural development (with Agenda 2000 programme), and the decoupling of direct payments from production according to certain conditions, whereby producers were no longer paid according to the quantities they produced, but based on the quality of the production process (2003 Fischler reform) (on the CAP reforms see, inter alia, Garzon 2006; Cuhna and Swinbank 2011; Swinnen 2015; Papadopoulos 2015b; Corrado et al. 2018).

In other words, payment is increasingly subject to compliance with the rules on environmental protection, food safety, animal and plant health and animal welfare, 
as well as with the obligation to maintain the land in good agricultural and ecological conditions. Payments are increasingly "rewards" which are greater for those farmers able to carry out measures of greening and agricultural biodiversity (for example with the preservation of native breeds, the diversification of crops, the maintenance of permanent grasslands and the care of the forest). A series of incentives are provided for those who work inland, in disadvantaged, remote and/or poorly connected areas, with a view to counter depopulation and abandonment, for example with incentives that encourage youth entrepreneurship, organic production and animal welfare practices.

\section{Box: The New Rural Development Paradigm}

According to Van der Ploeg et al. (2000: 392), a new rural development paradigm is taking place in both policy and practice, to contrast the negative effects of the modernization paradigm. Rural development (RD) is being "recognized as a multi-level process rooted in historical traditions". The focus is on re-embedding agriculture in the local society, in opposition to the tendency of modernization practices to segregate "agriculture" from the other rural activities. The RD paradigm is based on the idea that agriculture must be conceived as "multi-functional", producing not only agricultural commodities for the global market, but also services and collective goods. These are unique and non-transferable through markets, and include landscapes, natural values and agro-ecological biodiversity, local economy and social network to contrast rural abandonment. In this sense "many rural development experiences creating cohesion between activities, not only at farm level but also between different farms or farms and other rural activities, appear to be a crucial, strategic element. Particularly important are the (potential) synergies between local and regional eco-systems (Guzman Casado et al. 2000), specific farm styles, specific goods and services, localized food-chains and finally, specific social carriers and movements" (Van der Ploeg et al. 2000: 393). The territorial constraints become specific and non-imitable resources for place-based development paths. The local household farm is central to this process, with its ability to create value through economies that are alternative to neoliberal markets and embedded in relational and local circuits (what are defined as nested markets).

Following WTO agreements, CAP progressively moved towards stronger market orientation and agricultural sustainability, with an enhanced concern for quality processes and products (i.e., organic agriculture certifications and denominations of origin quality control). However, the related distorting effects mostly favoured food processors, the agrochemical industry, and large farms, but also export-oriented food traders and large retailers, with a controversial impact on developing countries. Some crops, territories, actors and companies have been more able than others to benefit from such schemes, with medium and large farms typically being favoured. 
Similarly, EU support for producer organizations (POs) is criticised as having failed to enhance collective actions and reduce the fragmentation of farmers, while it favoured the cooperation of the most powerful and economically important stakeholders in the sector (Corrado et al. 2018).

While claiming support to small producers the role of the EU has often had the opposite effect by reorganizing agri-food chains in a neoliberal framework, which eventually undermined the power and the capacities of agricultural producers, whom have lost out in this process. Trade liberalization policies in recent years have reconfigured value chain dynamics through regulations concerning food safety, packaging, distribution and retailing, which eventually distorted power relations in favour of large industries and distribution corporations. Standards, certifications, and regulatory adjustments imposed by EU policies are often costly constraints and barriers to entry to markets that undermine the survival of small independent producers. As a result, farmers and rural producers have become the main shock absorbers of market risks resulting from the policy-assisted reconfiguration of agrifood value chains.

The modernisation of the agricultural sector resulted in an important polarisation of the territorial as well as social landscapes. On the one hand areas with higher potential for agriculture (ie. low plains, valley bottoms, coastal areas) have undergone intensification of agriculture production, while on the other hand more marginal settings where the potential for agricultural intensification is structurally limited, have witnessed a progressive abandonment.

Throughout the Mediterranean marginal communities, inhabiting mountainous, island territories or inner areas have carried the higher burden with entire territories depopulated, agricultural surfaces abandoned, and rural villages emptied through forms of socio-economic desertification. The climatic, financial and political crises that have characterised the last decade (and that are closely intertwined, as properly noted by Klein 2016) have compounded a polarised situation that was already quite stretched for Mediterranean agriculture and rural areas.

Overall the implications of such reconfiguration of agro-ecological and socioeconomic landscapes have been dramatic. Family farming has become a decreasingly viable enterprise, while opportunities for agricultural workers have been jeopardised by the growing mechanisation on higher potential areas and by land abandonment in lower potential ones. Although each country has experienced different rates and modalities, such processes have altogether implied an important movement of populations out of rural areas.

Despite its relevant engagement, the EU's "rural welfare" scheme is increasingly criticized for its inability to offset the negative social and environmental trends affecting the EU agrarian world. Farmers in Europe increasingly rely on subsidy schemes, rural populations continue to decline, and remain socially and politically marginalised. Compared to neighboring urban areas, today the living conditions in EU rural areas are tougher, the quality of basic services and facilities are inferior and limited, and opportunities for employment and income are lower.

These features make living and working in the countryside an unattractive option for the local youth, who often tends to seek livelihood opportunities elsewhere. 


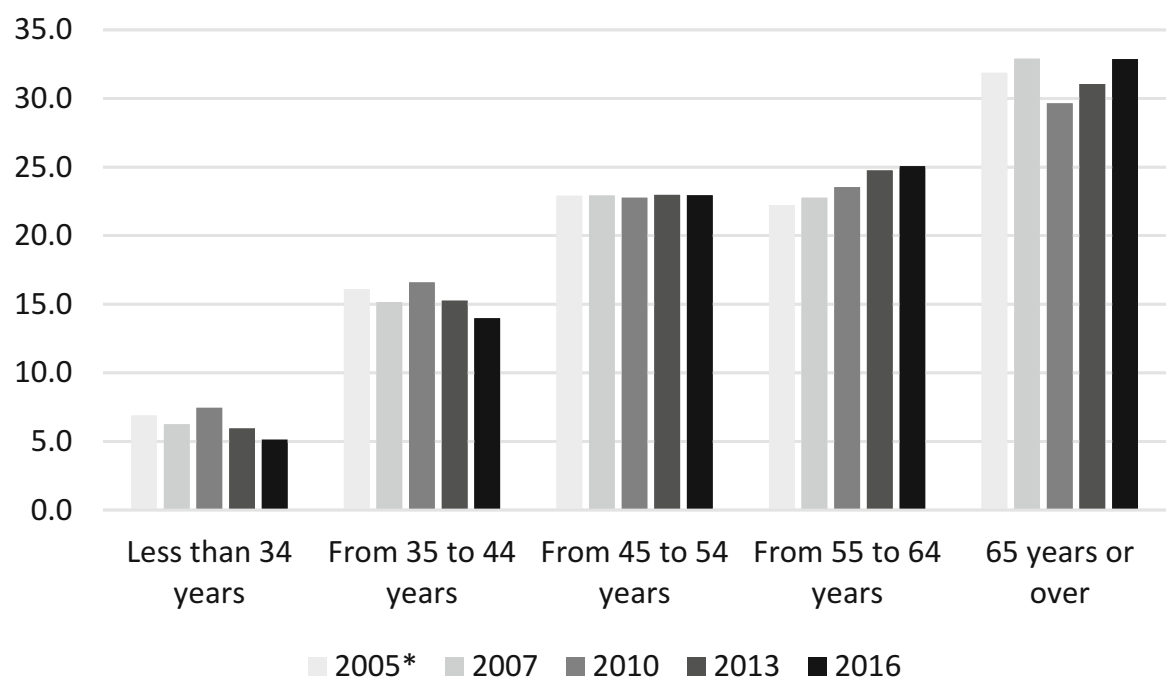

Fig. 2.2 Farmers by age (\%) in EU-28. (Source: our re-elaboration on EUROSTAT, see https:// ec.europa.eu/eurostat/web/agriculture/data/database. Map Legend: 2005 is on EU-27)

Similarly, to most rural areas throughout the world, a marking feature of the EU's countryside is the emigration of its rural youth, which leads in turn to the demographic aging of rural communities and problems of workforce availability and generational renewal in agricultural enterprises (refer to Fig. 2.2). In $201655 \%$ of EU-28 farmers are aged 55 years or more, and $32.8 \%$ are aged over 65 . These values have increased compared to 2005, when the farmers aged 55 or more were the $54.1 \%$ and the farmers aged over 65 were $31.9 \%$. The percentage of female farms remain still very low: $28.4 \%$ in 2016 .

In the EUMed, agriculture is losing 2-3\% of its active population per year. Today only one out of every ten farmers across the EUMed is younger than 35 years, while the percentage of the population aged over 65 represents more than $20 \%$ of those inhabiting rural areas (Table 2.1). Portugal leads the group with $22.7 \%$ of its rural population in this age group, followed by Greece $(21.4 \%)$, Spain $(21.1 \%)$, Italy (20.9\%) and France (20.8\%). Essentially, in the EUMed, agricultural labour force is older than in any other sector of the economy. These data lead to serious concerns about an increasingly ageing and dependent population in many rural areas, and structural consequences including land abandonment, depopulation, and lack of services which will further reduce the attractiveness of living in rural areas (Dollé 2011; Collantes and Pinilla 2011; Arnalte-Alegre and Ortiz-Miranda 2013; Collantes et al. 2014; Camarero and del Pino 2013; Campagne and Pecqueur 2014; Leavy and Hossain 2014; Papadopoulos 2015; Corrado et al. 2016b; Nori 2016; Farinella et al. 2017).

These dynamics have led to significant agrarian change over the last three decades, as the number of farms has steadily decreased, as it has, to a lesser extent, 
Table 2.1 Basic statistics and trends of EUMed agriculture

Average farm size UAA (hectare)

\begin{tabular}{l|l|l|l|l}
\hline & Greece & Spain & Italy & EU 28 average \\
\hline 1990 & 4.3 & 15.4 & 5,6 & \\
\hline 2000 & 4.4 & 20.3 & 6.1 & $12.8^{\mathrm{a}}$ \\
\hline 2010 & 7.2 & 24 & 8 & $14.4($ EU 28) \\
\hline 2016 & 6.6 & 24.6 & 11 & $16.6($ EU 28) \\
\hline
\end{tabular}

Utilised agricultural area (UAA) (hectare)

\begin{tabular}{l|l|l|l|l}
\hline & Greece & Spain & Italy & EU 28 average \\
\hline 1990 & 3.661 .210 & 24.531 .060 & 14.946 .720 & \\
\hline 2000 & 3.583 .190 & 26.158 .410 & 13.062 .260 & $200.462 .070^{\mathrm{a}}$ \\
\hline 2010 & 5.177 .510 & 23.752 .690 & 12.856 .050 & 175.845 .490 \\
\hline 2016 & 4.553 .830 & 23.229 .750 & 12.598 .160 & 173.338 .550 \\
\hline$\%$ Decr/Incr. In 2000-16 & 27.1 & -11.2 & -3.6 & $-13.5(\mathrm{y} .2003)$ \\
\hline
\end{tabular}

Farm holdings (quantity)

\begin{tabular}{l|l|l|l|l}
\hline & Greece & Spain & Italy & EU 28 average \\
\hline 1990 & 850.140 & 1.593 .640 & 2.664 .550 & \\
\hline 2000 & 817.060 & 1.287 .420 & 2.153 .720 & $15.669 .410^{\mathrm{a}}$ \\
\hline 2010 & 723.060 & 989.800 & 1.620 .880 & 12.245 .700 \\
\hline 2016 & 684.950 & 945.020 & 1.145 .710 & 10.467 .760 \\
\hline$\% 2000-16$ rate drop & -16.2 & -26.6 & -46.8 & -33.2 \\
\hline
\end{tabular}

Employment in agriculture (total)

\begin{tabular}{l|l|l|l}
\hline & Greece & Spain & Italy \\
\hline 2000 & $1.4 \mathrm{mil}$ & $2.4 \mathrm{mil}$ & $4 \mathrm{mil}$ \\
\hline 2010 & $1.2 \mathrm{mil}$ & $2.2 \mathrm{mil}$ & $3.4 \mathrm{mil}$ \\
\hline$\% 1990-2010$ Rate drop in agricultural employment & $-15 \%$ & $-8.7 \%$ & $-14 \%$ \\
\hline
\end{tabular}

Employment in agriculture (\% of total employment)

\begin{tabular}{l|l|l|l}
\hline & Greece & Spain & Italy \\
\hline 2000 & 17.4 & 6.7 & 5.2 \\
\hline 2010 & 12.4 & 4.2 & 3.8 \\
\hline 2018 & 11.9 & 4.0 & 3.9 \\
\hline
\end{tabular}

Labour force directly employed (LFE) - annual working unit

\begin{tabular}{l|l|l|l|l}
\hline & Greece & Spain & Italy & EU 28 average \\
\hline 1990 & 680.330 & 1.143 .350 & 1.923 .990 & \\
\hline 2000 & 587.480 & 1.077 .730 & 1.364 .920 & $14.229 .940^{\mathrm{a}}$ \\
\hline 2010 & 429.520 & 888.970 & 953.790 & 9.943 .950 \\
\hline 2016 & 448.220 & 801.160 & 874.950 & 9.108 .100 \\
\hline$\% 2000-16$ Drop in LFE & -23.7 & -25.7 & -35.9 & -36.0 \\
\hline
\end{tabular}

Farm indicators by sex and age of the manager (\%)

\begin{tabular}{l|l|l|l|l|l}
\hline Variable & Year & Greece & Spain & Italy & EU 28 \\
\hline \multirow{2}{*}{ \% Farmers aged over 65 } & 2016 & 33.5 & 31.2 & 40.9 & 32.8 \\
\cline { 2 - 6 } & 2005 & 35.9 & 30.6 & 41.4 & 31.9 \\
\hline \multirow{2}{*}{ \% Farmers aged between 55 and 64 } & 2016 & 27.4 & 25.4 & 24.0 & 25.0 \\
\cline { 2 - 6 } & 2005 & 20.9 & 24.5 & 24.6 & 22.2 \\
\hline
\end{tabular}


Table 2.1 (continued)

Farm indicators by sex and age of the manager (\%)

\begin{tabular}{l|l|l|l|l|l}
\hline Variable & Year & Greece & Spain & Italy & EU 28 \\
\hline \% Farmers aged until 34 & 2016 & 3.7 & 3.8 & 4.1 & 5.1 \\
\cline { 2 - 6 } & 2005 & 6.7 & 6.0 & 3.5 & 6.9 \\
\hline \multirow{2}{*}{ \% Female farms } & 2016 & 27.5 & 22.5 & 31.5 & 28.4 \\
\hline & 2005 & 25.2 & 19.0 & 27.9 & 26.3 \\
\hline
\end{tabular}

Source: Our elaboration on Eurostat (https://ec.europa.eu/eurostat/web/agriculture/data/database) and ILOSTAT (2019). Map Legend: ${ }^{a}=$ year 2003, because 2000 is not available for EU 28

the utilized agricultural area (UAA), while the average size of farms has grown (EU 2011, 2012, 2013, 2017).

While these trends show regional as well as global patterns, data and rates are though particularly high in the European context and specifically in its Mediterranean rims. In the EU-28, farm holdings declined by $40 \%$ between 2003 and 2016 and the farm size grew from 12.8 ha of UAA in 2003 to 16.6 ha in 2016 . In the same period EU-28 countries lost much agricultural land (-13.5\%), passing from approximately 200 million hectares in 2003 to 173 million in 2016. The directly employed agricultural labour force, calculated in annual working units, decreased by $36 \%$.

Table 2.1 offers a general idea about these transformations for the EUMed countries, where the number of farms decreased consistently between 1990 and 2016, a reduction largely due to the drop in the number of small farms, while the size of average farms increased. These statistics are particularly worrying especially when thinking about the huge and longstanding political and financial investments of the CAP.

In Greece there were 684.950 agricultural holdings in 2016, a 16\% drop with 132.110 farms ceasing their activity since 2000. Agricultural labour force also decreased by $15 \%$ from 1.4 million in 2000 to 1.2 million in 2010 . During that same period labour force directly employed in agriculture dropped by $23.7 \%$. The impact of the economic crisis that began in Greece in 2009, leading to the adoption of a stability program in collaboration with international lenders, had and is still carrying dramatic consequences on the Greek economy and society. Gross domestic product fell by about a fourth, while unemployment increased by almost $20 \%$ of the total workforce in few years (Eurostat 2015; ELSTAT 2015).

In such stretched setting agriculture remains an important source of livelihood for most rural areas. However the age of the farm heads is very high: in 2016, 33.5\% of farmers are aged over 65 and $60.9 \%$ are aged over 55. Salaried labour in agriculture does not seem an appealing option for local workforce; most agricultural workers are thus foreign, and immigrants have played an important role in supporting the survival, expansion and modernisation of farms as well as in their resilience in the current crisis (Kasimis and Papadopolus 2013; Ragkos et al. 2015, 2016).

In Spain there were 945.020 agricultural holdings in 2016, a 26.6\% drop compared to 2000. In the same decade the land utilised for agricultural purposes 
decreased by $11.2 \%$, while labour force directly employed in agriculture dropped by $25.7 \%$. During that same time span the average farm size increased, passing from 15.4 (hectares/farm) in 1990 to 24.6 in 2016, while the average age of farmers slightly increased: in the 2005, 55.1\% of farmers was aged over 55, in 2016 this is the 56.6\%: just under one farmer every three is over 65 years old.

Between 2000 and 2010 the employment in agriculture passed from 2.4 million to 2.2 million (about 10\% of the economically active population). Since the 1980s and 1990 s, the development of intensive agriculture started relying on migrant workers, predominantly employed in an irregular manner through informal networks. Since the 2000s, agricultural work relations were formalized through mechanisms that aimed to serve the needs of a very flexible industry that had become increasingly specialized (Ortiz-Miranda et al. 2013; Corrado et al. 2016b).

In Italy there were 1.145 .710 agricultural holdings in 2016, the third largest amount within the EU-28, after Romania and Poland. In 2000 the number of holdings was 2.153 million: in 16 years about $46.8 \%$ of the farms had ceased their activity. During the same period, the average size farm almost doubled, passing from 6.1 hectare/farm in 2000 to 11 hectare/farm in 2016. Today Italy has the third highest percentage of farmers aged over 65: 40.9\% in 2016, after Romania (44.3\%) and Cyprus $(44.6 \%)$.

This process of concentration and modernization is also evident when looking at the decrease in agricultural work: the amount of persons working in agriculture dropped of about $14 \%$ in 2000-2010, from 4 to 3,four million; the labour force directly employed, calculated in annual working unit, dropped of $35.9 \%$ in 2000-2016. If we consider that in 2010 the agricultural labour force still represented $14 \%$ of the economically active population, it can be inferred that an important proportion of work is still informal, and it is carried out, as we will see, by migrant workers. A Caritas report indicated in 2014:

\footnotetext{
Italian agriculture products are in the hands of foreign workers, accounting for about $25 \%$ of the total number of employment days in the food industry. (...) Foreign workers are contributing in a structural and critical way to the country's agricultural economy and are a much-needed component in ensuring the excellence of Italian food in the world.
}

Data from INEA seems to confirm these indications (refer to Fig. 2.3).

A comprehensively critical assessment of the CAP and of European Policies today would recognise their contribution in consolidating, and to an extent even widening, sectoral, social, generational and territorial inequalities. CAP has provided proportional advantages to larger farms and companies, higher-potential areas, intensive production systems and specialized agricultural enclaves. Conversely, and as a consequence, family farming and extensive agricultural systems have undergone dramatic processes of abandonment. The arrival of immigrants in rural areas has enabled tackling these dynamics, by countering the demographic decline and matching the demand for low-cost and flexible labour (Kasimis et al. 2010; Colloca and Corrado 2013; Caruso and Corrado 2015; Nori 2018; Farinella et al. 2017; ENRD 2018). 


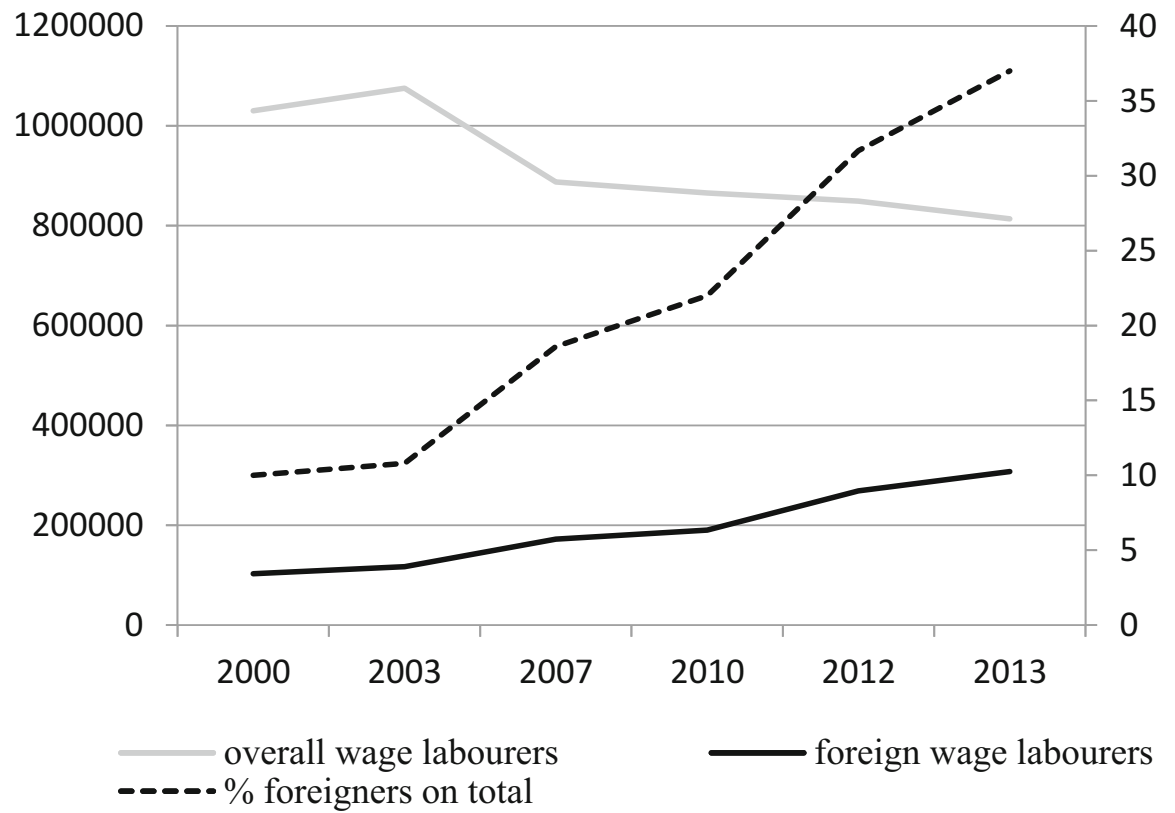

Fig. 2.3 Foreign workers in Italian agriculture (years 2000-2013). (Source: own elaboration on INEA data 2014)

In order to redress these dynamics recent CAP reforms allocate more emphasis on the wider rural context in which farming operates and its role in managing environmental, climatic as well as social matters. These principles inspired the CAP 2013 reform and are also present in the documents introducing the forthcoming one in 2020. In the EC communication The Future of Food and Farming (2017) specific mention is made of "generational renewal that should become a priority in a new policy framework" and tailored schemes that must be developed to "reflect the specific needs of young farmers" (EU 2017: 23). Moreover in the document there is an emphasis on that "the future CAP could play a larger role in addressing the root causes of migration" and that "the CAP can play a role in helping to settle and integrate legal migrants, refugees in particular, into rural communities".

\subsection{Conclusions}

In this chapter we highlighted the changes and dynamics that have affected European agriculture in recent decades, with a focus on the related implications and impacts for small-scale farmers and for marginal rural settings (Table 2.2). The processes of agricultural modernization and the oligopolistic restructuring of global agri-food 
Table 2.2 The relationships between the policy framework and the shaping of the field reality

\begin{tabular}{l|l|l}
\hline Process & Impacts & Implications \\
\hline Modernization & Territorial polarization & $\begin{array}{l}\text { Intensive agriculture in high-potential areas; } \\
\text { abandonment lower potential ones; youth } \\
\text { exodus }\end{array}$ \\
\hline $\begin{array}{l}\text { Value-chain } \\
\text { restructuring }\end{array}$ & Oligopolistic control & $\begin{array}{l}\text { Loss of food sovereignty and quality of the } \\
\text { production system; agricultural squeeze }\end{array}$ \\
\hline $\begin{array}{l}\text { Rural develop- } \\
\text { ment paradigm }\end{array}$ & $\begin{array}{l}\text { Contrasting socio-economic } \\
\text { and ecological downgrade }\end{array}$ & $\begin{array}{l}\text { Sinergy between agriculture and territory; } \\
\text { multi-functionality; local collective goods } \\
\text { and agro-ecological services; local and } \\
\text { alternative supply chain }\end{array}$ \\
\hline
\end{tabular}

Source: our elaboration

chains have generated socio-spatial marginalization, in the national territories as much as in the markets.

The consequences are borne by the whole society - producers, consumers, and citizens alike - whose capacity to influence food sovereignty, production quality and worker's rights has decreased. Despite important policy investments, several rural areas experience problems of environmental degradation and abandonment, thus adding to problems of desertification that are affecting different portions of the EUMed region.

Since the 2000s, a new rural development paradigm is emerging to contrast the modernization one, with a view to buffer the socio-economic downgrade of rural regions. This focuses on the idea to re-embed agriculture practices in the local society and ecosystems, enhancing the natural multi-functionality of agriculture and its capacity to produce also services and collective goods such as biodiversity, landscapes, tacit knowledge, local economy and social relations. These principles which would eventually look into the quality of the production process and also include the conditions of its workers has though not yet materialized in policy terms.

Through its economic, social and ecological implications the consequences of agricultural restructuring represent critical political issues. On the one hand the most fragile, inland and mountain territories face growing degrees of marginalization, increasingly emptied by demographic decline and land abandonment, facing socioeconomic desertification. On the other hand, territories with higher agricultural potentials suffer the burden of encroaching urbanization, agricultural intensification, pollution and overexploitation, with often irreversible outcomes. Risks and hazards associated to unsustainable management of natural resources have characterized recent important, tragic events all over the EUMed region. Farmers, the most critical but the weakest component of the supply chain, bear the brunt of the costs of reducing earnings, which pushes towards reducing production costs and often translates into exploitative regimes, including workers. These workers are often, and increasingly, of foreign origin. Their presence significantly contributes to redress the social and economic mismatch affecting EUMed agrarian worlds, by filling the gaps left by local populations. The living and working conditions of rural immigrants are strictly regulated by a policy framework which provides them with limited and 
ineffective rights. The principles inspiring the CAP and its generous hand-outs are informed by animal welfare, organic production, food safety much more then by their care for the rights and conditions of agricultural workers (Corrado et al. 2018).

In the following chapters we try addressing some of these critical issues in relation to the migrant workers in rural regions.

\section{References}

AGCM (Autorità Garante della Concorrenza e del Mercato) (2013). Indagine conoscitiva sul settore della GDO. Rome: AGCM

Agnoletti, M. (Ed.). (2013). Italian historical rural landscapes. Cultural values for the environment and rural development. Dordrecht: Springer.

Agnoletti, M., \& Emanueli, F. (Eds.). (2016). Biocultural diversity in Europe. Berlin: Springer.

ANGED (Asociación Nacional Grandes de Empresas de Distribución) (2014). Informe annual, 2014. Madrid: ANGED.

Arnalte-Alegre, E., \& Ortiz-Miranda, D. (2013). The 'Southern Model' of European agriculture revisited: Continuities and dynamics. In D. Ortiz-Miranda, A. Moragues-Faus, \& E. ArnalteAlegre (Eds.), Agriculture in Mediterranean Europe: Between old and new paradigms (Research in rural sociology and development, Vol. 19, pp. 37-74). Bradford: Emerald Group Publishing Limited.

Bharadwaj, L., Findeis, J. L., \& Chintawar, S. (2013). Motivations to work off-farm among US farm women. Journal of Socio-Economics, 45, 71-77. https://doi.org/10.1016/j.socec.2013.04.002.

Burch, D., \& Lawrence, G. (Eds.). (2007). Supermarkets and Agri-food supply chains. Transformations in the production and consumption of foods. Cheltenham: Edward Elgar.

Burch, D., \& Lawrence, G. (2013). Financialization in agri-food supply chains: Private equity and the transformation of the retail sector. Agriculture and Human Values, 30, 247-258. https://doi. org/10.1007/s10460-012-9413-7.

Burch, D., Dixon, J., \& Lawrence, G. (2013). Introduction to symposium on the changing role of supermarkets in global supply chains. From seedling to supermarket: Agri-food supply chains in transition. Agriculture and Human Values, 30, 215-224. https://doi.org/10.1007/s10460-0129410-x.

Camarero, L., \& Del Pino, J. A. (2013). Impacts of ageing on socioeconomic sustainability in Spanish rural areas. In M. Gather (Ed.), Proceedings of the 2nd Eurufu scientific conference: Education, local economy and job opportunities in rural areas (pp. 79-89). Erfurt: Institut Verkehrund Raum.

Campagne, P., \& Pecqueur, B. (2014). Le développement territorial: une réponse émergente à la mondialisation. Paris: Fondation Charles Léopold Mayer.

Caritas. (2014). Dossier statistico immigrazione 2014 (Rapporto Unar). Roma: Portale Integrazione Migranti.

Caruso, F., \& Corrado, A. (2015). Migrazioni e lavoro agricolo: un confronto tra Italia e Spagna in tempi di crisi. In M. Colucci \& S. Gallo (Eds.), Tempo di cambiare: Rapporto 2015 sulle migrazioni interne in Italia. Roma: Donzelli.

Centre for European Policy Studies. (2015). In J. Swinnen (Ed.), The political economy of the 2014-2020 common agricultural policy. An imperfect storm. London: Rowman\& Littlefield International.

Collantes, F., \& Pinilla, V. (2011). Peaceful surrender: The depopulation of rural Spain in the twentieth century. Newcastle-upon-Tyne: Cambridge Scholars Publishing.

Collantes, F., Pinilla, V., Sàez, L. A., \& Silvestre, J. (2014). Reducing depopulation in rural Spain. Population, Space and Place, 20, 606-621. https://doi.org/10.1002/psp.1797. 
Colloca, C., \& Corrado, A. (Eds.). (2013). La globalizzazione delle campagne (Migranti e società rurali nel Sud Italia). Milano: FrancoAngeli.

Corrado, A., De Castro, C., \& Perrotta, D. (2016a). Introduction. Cheap food, cheap labour, high profits. Agriculture and mobility in the Mediterranean migration and agriculture. In A. Corrado, C. De Castro, \& D. Perrotta (Eds.), Mobility and change in the Mediterranean area (pp. 1-46). London/New York: Routledge.

Corrado, A., De Castro, C., \& Perrotta, D. (Eds.). (2016b). Mobility and change in the Mediterranean area. London/New York: Routledge.

Corrado, A., Palumbo L., Caruso F. S., M.Lo Cascio., Nori M., Traindafyllidou, A., (2018). Is Italian agriculture a 'Pull Factor' for Irregular Migration - and, if so, why?, Open Society Foundations. https://www.opensocietyfoundations.org/sites/default/files/is-italian-agriculturea-pull-factor-for-irregular-migration-20181205.pdf. Accessed 20 Jan 2019.

Cuhna, A., \& Swinbank, A. (2011). An inside view of the CAP reform process, explaining the MacSharry, agenda 2000 and Fischler reforms. Oxford: Oxford University Press.

Dixon, J. (2007). Supermarkets as new food authorities. In D. Burch \& G. Lawrence (Eds.), Supermarkets and agri-food supply chains: Transformations in the production and consumption of foods (pp. 29-50). Cheltenham: Edward Elgar.

Dollé, V. (2011). Food security and agriculture in the Mediterranean: Crisis scenario and prospects for 2030. In Tomorrow the Mediterranean (Scenarios and projections for 2030). Paris: IPEMED.

EC. (2009). A better functioning food supply chain in Europe. A view to promoting quality and safe food products at affordable prices. Bruxelles: European Commission. http://europa.eu/rapid/ press-release_MEMO-09-483_en.htm?locale=en.

ELSTAT. (2015). Greek statistical authority. http://tinyurl.com/jejuhgs

ENRD. (2018). Strategy for inner areas. Italy: European Network for Rural Development. https:// enrd.ec.europa.eu/sites/enrd/files/tg_smart-villages_case-study_it_0.pdf.

EU. (2011). Impact assessment of the CAP reform. Bruxelles: European Commission. https://ec. europa.eu/agriculture/sites/agriculture/files/policy-perspectives/impact-assessment/captowards-2020/report/full-text_en.pdf.

EU. (2012). Rural development in the EU statistical and economic information. Bruxelles: EC DG Agriculture. https://ec.europa.eu/agriculture/statistics/rural-development_en.

EU. (2013). The CAP towards 2020: Meeting the food, natural resources and territorial challenges of the future. Bruxelles: EC DG Agriculture. http://ec.europa.eu/dorie/fileDownload.do; jsessionid=nxRcuiAAqmbkiw5FbJPj4u6gT9cczLOYbz9mDWZDxNrd1Pam0cYs! 1583997504 ? docId $=1336699 \&$ cardId $=1336698$.

EU. (2017). The future of food and farming. Communication from the Commission to the European Parliament, the Council, the European Economic and Social Committee and The Committee of the Regions. Draft document introducing the CAP 2020 Reform https://ec.europa.eu/agricul ture/sites/agriculture/files/future-of-cap/future_of_food_and_farming_communication_en.pdf

Eurostat. (2015). Agriculture, forestry and fishery statistics, 2015th edition. Luxembourg: Eurostat.

Farinella, D., Nori, M., \& Ragkos, A. (2017). Change in Euro-Mediterranean pastoralism: Which opportunities for rural development and generational renewal? In C. Porqueddu, A. Franca, G. Molle, G. Peratoner, \& A. Hokings (Eds.), Grassland reources for extensive farming systems in marginal lands: major drivers and future scenarios (Vol. 22, pp. 23-36). Wageningen: Grassland Science in Europe. Wageningen Academic Publishers.

Friedmann, H. (2005). From colonialism to green capitalism: Social movements and the emergence of food regimes. In H. Buttel, P. McMichael, \& P. Oxford (Eds.), New directions in the sociology of global development (pp. 229-267). Oxford: Elsevier.

Fritz, T. (2011). Globalising hunger: Food security and the EU's common agricultural policy. Berlin: Verlag.

Garzon, I. (2006). Reforming the CAP: History of a paradigm change. Houndmills/Basingstoke/ Hampshire: Palgrave Macmillan. 
Gertel, J., \& Sippel, S. R. (Eds.). (2014). Seasonal workers in Mediterranean agriculture. The social costs of eating fresh. London: Routledge.

Guzman Casado, G. I., González de Molina, M., \& Sevilla Guzmán, E. (2000). Introduccion a la Agroecologia Como Desarrollo Rural Sostenible. Madrid: Ediciones Mundi-Prensa.

Hervieu, B., \& Purseigle, F. (2012). Sociologie des mondes agricoles. Paris: Armand Colin.

ILOSTAT. (2019). Employment in agriculture. https://data.worldbank.org/indicator/SL.AGR. EMPL.ZS?locations=IT-ES-GR\&view=chart. Accessed 20 Jan 2019.

INEA. (2014). Annuario dell'agricoltura Italiana, 2013. Roma: Istituto Nazionale di Economia Agraria.

IPCC. (2014). Fifth Assessment Report, Intergovernmental Panel on Climate Change. www.ipcc. $\mathrm{ch} /$ report/ar5/

Kasimis, C., \& Papadopoulos, A. G. (2013). Rural transformations and family farming in contemporary Greece. In D. Ortiz-Miranda, A. Moragues-Faus, \& E. Arnalte-Alegre (Eds.), Agriculture in Mediterranean Europe: Between old and new paradigms (Research in rural sociology and development, Vol. 19, pp. 283-293). Bradford: Emerald Group Publishing Limited.

Kasimis, C., Papadopoulos, A. G., \& Pappas, C. (2010). Gaining from rural migrants: Migrant employment strategies and socioeconomic implications for rural labour markets. Sociologia Ruralis, 50(3), 258-276. https://doi.org/10.1111/j.1467-9523.2010.00515.x.

Klein, N. (2016). Let them drown: The violence of othering in a warming world. London Review of Books, 38(11), 11-14. 5421.

Leavy, J., \& Hossain, N. (2014). Who wants to farm? Youth aspirations, opportunities and rising food prices. IDS Working Paper, 439, 1-44, https://doi.org/10.1111/j.2040-0209.2014.00439.x

Marsden, T., Banks, J., \& Bristow, G. (2000). Food supply chain approaches: Exploring their role in rural development. Sociologia Ruralis, 40, 424-438. https://doi.org/10.1111/1467-9523.00158.

McMichael, P., \& Friedmann, H. (2007). Situating the 'retailing revolution. In D. Burch \& G. Lawrence (Eds.), Supermarkets and Agri-food supply chains: Transformations in the production and consumption of foods (pp. 291-319). Cheltenham: Edward Elgar.

Moss, C. B. (1992). The cost-price squeeze in agriculture: An application of Cointegration. Review of Agricultural Economics, 14, 205-213.

Nori, M. (2016). Shifting transhumances: Migrations patterns in Mediterranean pastoralism. In CIHEAM, Watch letter 36. Crise et resilience en la Mediterranee. Montpellier. www.iamb.it/ share/integra_'les_lib/'les/WL36.pdf

Nori, M. (2017). Immigrant shepherds in Southern Europe. E-paper, Heinrich Böll Stiftung Foundation. https://www.boell.de/en/agriculture-food-production-and-labour-migration-south ern-europe

Nori, M. (2018). Agriculture and rural territories in the Mediterranean: The case for mountainous communities. In Mediterra (Ed.), Inclusion and migration challenges around the Mediterranean. Paris: CIHEAM.

Ortiz-Miranda, D., Moragues-Faus, A., \& Arnalte-Alegre, E. (2013). Agriculture in Mediterranean Europe: Between old and new paradigms (Research in Rural Sociology and Development, Vol. 19). Bingley: Emerald Group Publishing.

Oxfam. (2018). Human suffering in Italy's agricultural value chain. Oxfam International \& Terra.

Papadopoulos, A. G., (2015). In what way is Greek family farming defying the economic crisis? Ağr1, 43. https://agriregionieuropa.univpm.it/it/content/article/31/43/what-way-greek-familyfarming-defying-economic-crisis.

Papadopoulos, A. G. (2015b). The impact of the CAP on agriculture and rural areas of EU member states. Agrarian South: Journal of Political Economy, 4(1), 22-53. https://doi.org/10.1177/ 2277976015574054.

Ragkos, A., Theodoridis, A., Fachouridis, A., \& Batzios, C. (2015). Dairy farmers' strategies against the crisis and the economic performance of farms. Procedia Economics and Finance, $33,518-527$. 
Ragkos, A., Koutsou, S., \& Manousidis, T. (2016). In search of strategies to face the economic crisis: Evidence from Greek farms. South European Society and Politics, 21, 319-337. doi.org/ 10.1080/13608746.2016.1164916.

Reardon, T., Timmer, C. P., Barrett, C. B., \& Berdegue, J. (2003). The rise of supermarkets in Africa, Asia and Latin America. American Journal of Agricultural Economics, 85(5), $1140-1146$.

Richards, C., Bjørkhaug, H., Lawrence, G., \& Hickman, G. (2013). Retailer-driven agricultural restructuring-Australia, the UK and Norway in comparison. Agriculture and Human Values, 30, 235-245. https://doi.org/10.1007/s10460-019-09917-2.

Saugeres, L. (2002). Of tractors and men: Masculinity, technology and power in a French farming community. Sociologia Ruralis, 42, 143-159. https://doi.org/10.1111/1467-9523.00207.

Shield Dennis, A. (2009). The farm Price-Cost squeeze and U.S. farm policy. Congressional Research Service. 7-5700. www.crs.gov.

Skordili, S. (2013). "The sojourn of Aldi in Greece". Journal of Business and Retail Management Research, 8, 1, pp. 68-80.

SOFA. (2018). State of Food and Agriculture 2018 on 'Migration, agriculture and rural development'. http://www.fao.org/3/I9549EN/i9549en.pdf

UNEP. (2010). Security in the Horn of Africa: The implications of a drier, hotter and more crowded future. Nairobi: Global Environmental Alert Service, UN Environmental Programme.

Van der Ploeg, J. D. (2008). The new peasantries: Struggles for autonomy and sustainability in an era of empire and globalization. London: Earthscan.

Van der Ploeg, J. D. (2010). The food crisis, industrialized farming and the imperial regime. Journal of Agrarian Change, 10(1), 98-106. https://doi.org/10.1111/j.1471-0366.2009.00251.x.

Van der Ploeg, J. D. (2013). Peasants and the art of farming: A chayanovian manifesto. Winnipeg: Fernwood Publishing.

Van der Ploeg, J. D., Renting, H., Brunori, G., Knickel, K., Mannion, J., Mardsen, T., De Roest, K., Sevilla-Guzmán, E., \& Ventura, F. (2000). rural development: from practices and policies towards theory. Sociologia Ruralis, 40(4), 391-408.

Vorley, B. (2007). Supermarkets and agri-food supply chains in Europe: Partnership and protest. In D. Burch \& G. Lawrence (Eds.), Supermarkets and Agri-food supply chains: Transformations in the production and consumption of foods (pp. 245-269). Cheltenham: Edward Elgar.

Zagata, L., \& Sutherland, L. A. (2015). Deconstructing the 'young farmer problem in Europe': Towards a research agenda. Journal of Rural Studies, 38, 39-51.

Open Access This chapter is licensed under the terms of the Creative Commons Attribution 4.0 International License (http://creativecommons.org/licenses/by/4.0/), which permits use, sharing, adaptation, distribution and reproduction in any medium or format, as long as you give appropriate credit to the original author(s) and the source, provide a link to the Creative Commons license and indicate if changes were made.

The images or other third party material in this chapter are included in the chapter's Creative Commons license, unless indicated otherwise in a credit line to the material. If material is not included in the chapter's Creative Commons license and your intended use is not permitted by statutory regulation or exceeds the permitted use, you will need to obtain permission directly from the copyright holder.

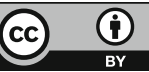

